\title{
Meningkatkan Keterampilan Menulis Deskripsi dengan Model Picture and Picture di SDN 3 Bangkleyan Kabupaten Blora
}

\author{
Ahmad Sholeh*, Veryliana, Darsimah \\ Program Studi Pendidikan Profesi Guru Pasca Sarjana Universitas PGRI Semarang \\ *Corresponding Author. Email: ahmadsholeh920@gmail.com
}

\begin{abstract}
The purpose of this study was to improve teacher skills, increase student activity, and improve student learning outcomes in writing descriptions through the application of the Picture and Picture model. This classroom action research was carried out in 3 cycles. The subjects of this study were the teacher and 18 second grade students of SDN 3 Bangkleyan. The research data in the form of quantitative data and qualitative data were analyzed using descriptive analysis techniques. From the results of the study it can be concluded that: (1) the skills of teachers in the first cycle got an average score of 29 with good criteria and in the second cycle got an average score of 31 with good criteria, the third cycle got an average score of 35 with very good criteria. (2) student activities in cycle I obtained an average score of 24 with sufficient criteria, in cycle II obtained an average score of 27 with good criteria, and in cycle III obtained an average score of 30 with good criteria. (3) student learning outcomes in the form of descriptive writing skills at the end of the first cycle obtained an average value of 65.5 and classical learning completeness $50 \%$, in the second cycle an average value of 69 and classical learning completeness of $69.4 \%$ cycle III got an average score of 79 and classical learning completeness of $83.3 \%$.
\end{abstract}

Abstrak: Tujuan penelitian ini adalah untuk meningkatkan keterampilan guru, meningkatkan aktivitas siswa, dan meningkatkan hasil belajar siswa dalam menulis deskripsi melalui penerapan model Picture and Picture. Penelitian tindakan kelas ini dilaksanakan dalam 3 siklus. Subjek penelitian ini adalah guru dan 18 siswa kelas II SDN 3 Bangkleyan. Data hasil penelitian berupa data kuantitatif dan data kualitatif yang dianalisis menggunakan teknik analisis deskriptif. Dari hasil penelitian dapat disimpulkan bahwa: (1) Keterampilan guru pada siklus I mendapat jumlah skor rata-rata 29 dengan kriteria baik dan pada siklus II mendapat jumlah skor rata-rata 31 dengan kriteria baik, siklus III mendapat jumlah skor rata-rata 35 dengan kriteria sangat baik. (2) Aktivitas siswa pada siklus I memperoleh jumlah skor rata-rata 24 dengan kriteria cukup, pada siklsus II memperoleh jumlah skor rata-rata 27 dengan kriteria baik, dan pada siklsus III memperoleh jumlah skor rata-rata 30 dengan kriteria baik. (3) Hasil belajar siswa berupa keterampilan menulis deskripsi pada akhir siklus I memperoleh nilai rata-rata 65,5 dan ketuntasan belajar klasikal 50\%, pada siklus II mendapat nilai rata-rata 69 dan ketuntasan belajar klasikal sebesar 69,4\%, pada akhir siklus III mendapat nilai rata-rata 79 dan ketuntasan belajar klasikal sebesar $83,3 \%$.

\author{
Article History \\ Received: 25-05-2021 \\ Revised: 09-06-2021 \\ Accepted: 25-06-2021 \\ Published: 07-07-2021
}

\section{Key Words: \\ Learning Outcomes, Writing Descriptions, Picture and Picture.}

\section{Sejarah Artikel}

Diterima: 25-05-2021

Direvisi: 09-06-2021

Disetujui: 25-06-2021

Diterbitkan: 07-07-2021

\section{Kata Kunci: \\ Hasil Belajar, Menulis Deskripsi, Model Picture and Picture.}

How to Cite: Sholeh, A., Veryliana, V., \& Darsimah, D. (2021). Meningkatkan Keterampilan Menulis Deskripsi dengan Model Picture and Picture di SDN 3 Bangkleyan Kabupaten Blora. Jurnal Paedagogy, 8(3), 454-459. doi:https://doi.org/10.33394/jp.v8i3.3910

https://doi.org/10.33394/jp.v8i3.3910

This is an open-access article under the CC-BY-SA License.

\section{Pendahuluan}

Belajar merupakan perubahan tingkah laku dengan serangkaian kegiatan misalnya dengan membaca, mengamati, mendengarkan, meniru dan lain sebagainya. Belajar akan lebih bermakna apabila subjek belajar mengalami atau melakukan sendiri kegiatan belajar tersebut 
(Sardiman, 2011). Proses pembelajaran merupakan proses interaksi yang intensif antar berbagai komponen sistem pembelajaran yaitu guru, siswa, materi belajar, dan lingkungan. Standar Proses adalah kriteria mengenai pelaksanaan pembelajaran pada satu satuan pendidikan untuk mencapai Standar Kompetensi Lulusan. Kompetensi adalah seperangkat sikap, pengetahuan, dan keterampilan, yang harus dimiliki, dihayati, dan dikuasai oleh Peserta Didik setelah mempelajari suatu muatan pembelajaran, menamatkan suatu program, atau menyelesaikan satuan pendidikan tertentu (PP No 13 Tahun 2015 Standar Nasional Pendidikan). Mata pelajaran bahasa Indonesia bertujuan agar peserta didik memiliki kemampuan: (1) berkomunikasi secara efektif dan efisien sesuai dengan etika yang berlaku, baik secara lisan maupun tulis; (2) menghargai dan bangga menggunakan bahasa Indonesia sebagai bahasa persatuan dan bahasa negara; (3) memahami bahasa Indonesia dan menggunakannya dengan tepat dan kreatif untuk berbagai tujuan; (4) menggunakan bahasa Indonesia untuk meningkatkan kemampuan intelektual, serta kematangan emosional dan sosial; (5) menikmati dan memanfaatkan karya sastra untuk memperluas wawasan, memperhalus budi pekerti, serta meningkatkan pengetahuan dan kemampuan berbahasa; (6) menghargai dan membanggakan sastra Indonesia sebagai khazanah budaya dan intelektual manusia Indonesia. Penggunaan bahasa sebagai alat komunikasi terbagi menjadi dua, yaitu komunikasi lisan dan komunikasi tulis. Menurut Santosa, (2008) komunikasi lisan meliputi keterampilan menyimak dan berbicara, sedangkan komunikasi tulis meliputi keterampilan membaca dan menulis. Untuk menumbuhkan budaya menulis deskripsi pada siswa, guru perlu membiasakan siswa dengan kegiatan menulis deskripsi dan menjadikan kegiatan menulis deskripsi sebagai suatu hal yang menyenangkan. Agar hal tersebut dapat tercipta, maka diperlukan proses pembelajaran yang menyenangkan dengan menerapkan model pembelajaran yang inovatif.

Menulis merupakan keterampilan berbahasa yang digunakan untuk berkomunikasi secara tidak langsung (Tarigan, 2008). Disamping itu, keterampilan menulis merupakan keterampilan berbahasa yang wajib dimiliki seorang siswa. Dalam menulis khususnya menulis karangan deskripsi siswa masih banyak mengalami kesulitan dalam hal mengembangkan ide pokok paragraf. Kesulitan siswa dalam mengembangkan ide pokok dikarenakan siswa susah untuk membedakan antara karangan narasi dengan karangan deskripsi yang menurut mereka memiliki ciri dan kemiripan (Jayanti et al, 2020).

Menulis termasuk kegiatan yang produktif dan ekspresif karena menulis berarti menyampaikan secara tertulis gagasan, ide, pendapat, atau pikiran dan perasaan Menulis memiliki peran yang penting karena dengan menulis maka seseorang dapat meningkatkan kecerdasan, mengembangka daya kreativitas, menumbuhkan keberanian, serta merangsang kemauan dan mengumpulkan informasi. Tulisan menjadi sarana komunikasi yang efisien dan efektif untuk menjangkau khalayak masa yang luas. Syarif (2009) mengatakan bahwa deskripsi merupakan jenis tulisan yang memaparkan atau menggambarkan dengan kata-kata suatu benda, tempat, suasana atau keadaan agar pembaca dapat melihat, mendengar, dan merasakan sendiri. Berdasarkan pendapat para ahli tersebut, maka peneliti berpendapat bahwa deskripsi merupakan jenis tulisan yang berisi gambaran mengenai suatu objek sehingga pembaca seolah-olah melihat, mendengar, merasakan atau mengalami langsung objek tersebut.

Untuk menjadikan siswa senang menulis diperlukan model pembelajaran yang menarik, salah satu model pembelajaran yang memiliki ciri inovatif, aktif, kreatif, dan menyenangkan adalah model Picture and Picture. Model pembelajaran adalah suatu rencana atau pola yang dapat digunakan untuk membentuk kurikulum (rencana pembelajaran jangka 
panjang), merancangbahan-bahan pembelajaran, dan membimbing pembelajaran di kelas atau yang lain (Joyce \& Weil dalam Rusman, 2011). Menurut Hamdani (2011) Model Picture and Picture merupakan suatu metode belajar yang menggunakan gambar yang dipasangkan atau diurutkan menjadi urutan logis. Suprijono (2009) mengemukakan langkah-langkah pembelajaran Picture and Picture, yaitu: guru menyampaikan kompetensi yang ingin dicapai, guru menya- jikan materi sebagai pengantar, guru menunjukkan/memperlihatkan gambargambar yang berkaitan dengan materi, guru menunjuk/memanggil siswa secara bergantian memasang/mengurutkan gambar-gambar menjadi urutan yang logis, guru menanyakan alasan/dasar pemikiran urutan gambar tersebut, guru memulai menanamkan konsep/materi sesuai dengan kompetensi yang ingin dicapai, kesimpulan/rangkuman.

Adapun tujuan penelitian ini adalah untuk meningkatkan keterampilan menulis deskripsi melalui penerapan model Picture and Picture pada siswa kelas II SDN 3 Bangkleyan Kabupaten Blora.

\section{Metode Penelitian}

Metode penelitian ini menggunakan penelitian tindakan kelas yang dilaksanakan dalam 3 siklus dimana setiap siklus terdiri dari 2 pertemuan, berikut gambar siklus yang akan digunakan.

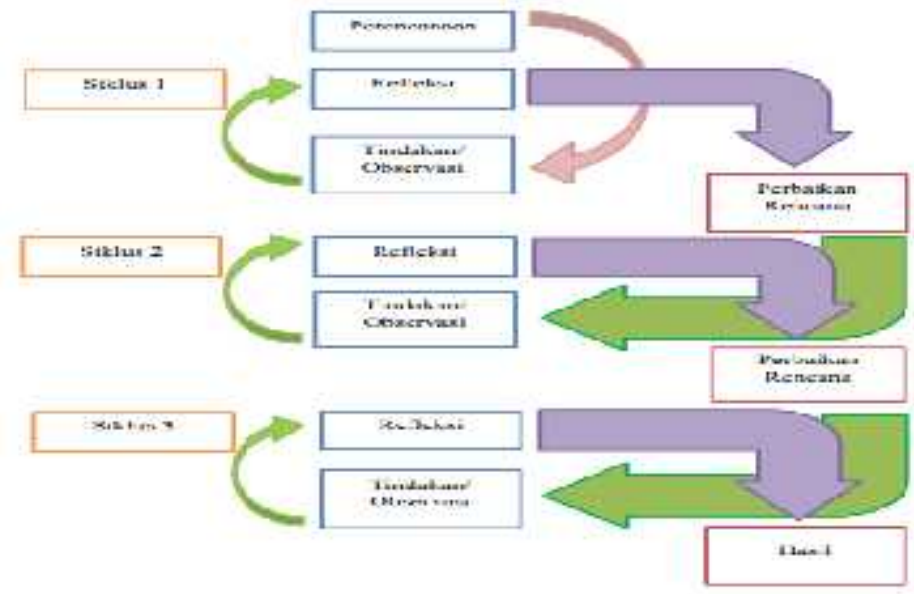

Gambar 1. Tahap-Tahap PTK Model Kemmis dan Mc Taggart

Perencanaan dilakukan sebelum seseorang melakukan suatu kegiatan agardapat berjalan baik sehingga dapat tercapai tujuan yang diharapkan. Arikunto (2010) dalam tahap perencanaan ini, peneliti menentukan titik atau fokus peristiwa yang perlu mendapat perhatian khusus untuk diamati, kemudian membuat sebuah instrumen pengamatan untuk membantu peneliti merekam fakta yang terjadi selama tindakan berlangsung. Peneliti melakukan perencanaan sebelum melakukan tindakan berupa kegiatan menelaah $\mathrm{SK}, \mathrm{KD}$, indikator, dan materi pembelajaran bahasa Indonesia kelas II, menyusun RPP sesuai dengan model Picture and Picture, menyiapkan media berupa gambar, menyiapkan Lembar Kerja Siswa dan evaluasi, serta membuat lembar observasi keterampilan guru dan aktivitas siswa. Tahap kedua dari penelitian adalah pelaksanaan yang merupakan penerapan isi rancangan mengenai tindakan di kelas (Arikunto, 2010). Dalam pelaksanaan tindakan peneliti berperan sebagai guru dan pengumpul data. Pelaksaanaan Penelitian Tindakan Kelas ini direncanakan dalam dua siklus. Setiap siklus terdiri dari tiga kali pertemuan. Arikunto (2010) menyatakan bahwa observasi adalah kegiatan penga- matan yang dilakukan oleh pengamat. Pengumpulan data pada penelitian tindakan kelas ini melalui observasi langsung. Observasi yang dilakukan 
bertujuan untuk mengetahui tingkat keterampilan guru dalam mengelola pembelajaran dan aktivitas siswa dalam pembelajaran menulis deskripsi melalui penerapan model Picture and Picture. Hal ini berarti bahwa pelaksanaan observasi bersamaan waktunya dengan pelaksanaan tindakan. Observasi dilaksanakan dengan bantuan dari guru kolaborator dan teman sejawat untuk mengamati keterampilan guru dan aktivitas siswa selama proses pembelajaran berlangsung. Pelaksanaan observasi dilakukan dengan menggunakan instrumen observasi berupa lembar pengamatan yang telah disiapkan dalam tahap perencanaan. Refleksi merupakan kegiatan untuk mengemukakan kembali apa yang sudah dilakukan (Arikunto, 2010). Peneliti melakukan refleksi yaitu mencoba mere- nungkan atau mengingat serta menghubungkan kejadian interaksi di kelas. Peneliti mengkaji proses pembelajaran yaitu keterampilan guru, aktivitas dan hasil belajar siswa berupa keterampilan menulis deskripsi menggunakan model Picture and Picture serta melihat ketercapaian indikator penelitian pada setiap siklus. Melalui refleksi ini, dinilai efektivitas model yang digunakan dengan mengacu pada indikator yang telah ditetapkan. Tindak lanjut untuk siklus berikutnya ditentukan berdasar atas masalah atau kesulitan yang muncul pada pelaksanaan tindakan siklus sebelumnya

Subjek penellitian ini adalah guru dan siswa kelas II sebanyak 18 siswa yang terdiri atas 10 siswa laki-laki dan 8 siswa perempuan. Penelitian ini dilaksanakan di SDN 3 Bangkleyan Blora. Teknik pengumpulan data pada penelitian ini adalah teknik tes dan nontes. Teknik non tes terdiri dari observasi, dokumentasi, dan catatan lapangan. Sedangkan teknik analisis data penelitian ini menggunakan analisis deskriptif kualitatif dan kuantitatif.

\section{Hasil Penelitian dan Pembahasan}

Penelitian tindakan ini dilaksanakan dalam 3 siklus penelitian, masing-masing siklus 2 pertemuan. Subjek penelitian ini adalah guru dan 18 siswa kelas II SDN 3 Bangkleyan. Data hasil penelitian berupa data kualitatif yang dianalisis menggunakan teknik analisis deskriptif. Variabel penelitian ini adalah (1) keterampilan guru, (2) aktivitas siswa, dan (3) hasil belajar. Setelah melakukan penelitian diperoleh data sebagai berikut:

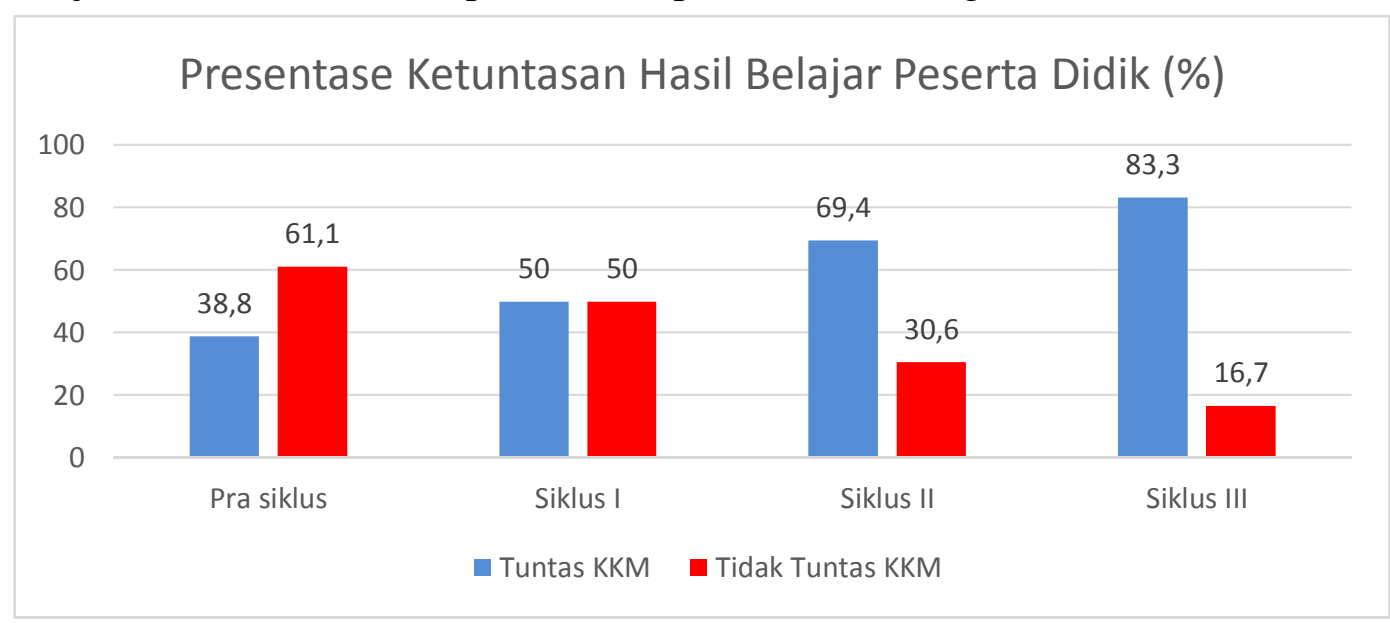

Diagram 1. Peningkatan Hasil Belajar Peserta Didik

Dari hasil penelitian dapat diketahui bahwa: (1) keterampilan guru pada siklus I mendapat jumlah skor rata-rata 29 dengan kriteria baik dan pada siklus II mendapat jumlah skor ratarata 31 dengan kriteria baik, siklus III mendapat jumlah skor rata-rata 35 dengan kriteria sangat baik. (2) aktivitas siswa pada siklus I memperoleh jumlah skor rata-rata 24 dengan kriteria cukup, pada siklsus II memperoleh jumlah skor rata-rata 27 dengan kriteria baik, dan 
pada siklsus III memperoleh jumlah skor rata-rata 30 dengan kriteria baik. (3) hasil belajar siswa berupa keterampilan menulis deskripsi pada akhir siklus I memperoleh nilai rata-rata 65,5 dan ketuntasan belajar klasikal 50\%, pada siklus II mendapat nilai rata-rata 69 dan ketuntasan belajar klasikal sebesar 69,4\%, pada akhir siklus III mendapat nilai rata-rata 79 dan ketuntasan belajar klasikal sebesar 83,3\%.

Hasil penelitian ini sejalan dengan penelitian Lestari dengan judul "Peningkatan Keterampilan Menulis Cerita Pendek dengan Model Pembelajaran Picture And Picture pada Siswa Kelas II SD Negeri 01 Jaten Karanganyar Tahun Pelajaran 2010/2011”. Peningkatan ini dapat dilihat dari hasil tes menulis cerita pendek siswa yang menunjukkan adanya peningkatan yaitu pada pra tindakan nilai rata-rata kelas 57,4 dengan ketuntasan klasikal 41\%. Pada siklus I menunjukkan nilai rata-rata kelas mencapai 59,7 dan ketuntasan klasikal meningkat menjadi 59\%. Pada siklus II nilai rata-rata kelas meningkat menjadi 66,1 dan ketuntasan klasikal meningkat menjadi $79 \%$. Selanjutnya penelitian yang dilakukan oleh Miftachudin dengan judul "Peningkatan Keterampilan Menulis Narasi Melalui Model Picture and Picture pada Siswa Kelas III SDN Turi 2 Kota Blitar" menunjukkan bahwa penerapan model pembelajaran Picture and Picture dapat meningkatkan keterampilan menulis narasi. Peningkatan keterampilan menulis narasi dapat ditunjukkan dengan nilai ratarata siswa pada siklus 1 yaitu 74 meningkat menjadi 81 atau persentase ketuntasan $74 \%$ meningkat menjadi $94 \%$ pada siklus 2. Dari 11 siswa yang tuntas belajar pada siklus 1 meningkat menjadi 32 siswa pada siklus 2. Berdasarkan penelitian-penelitian di atas bahwa model pembelajaran Picture and Picture terbukti dapat meningkatkan keterampilan menulis khususnya dalam menullisdeskripsi.

\section{Kesimpulan}

Simpulan dari penelitian ini adalah penerapan model Picture and Picture dapat meningkatkan keterampilan guru dalam mengajar, siswa menjadi aktif dalam pembelajaran, dan hasil belajar berupa keterampilan menulis deskripsi siswa kelas II SDN 3 Bangkleyan mengalami kenaikan.

\section{Saran}

Berdasarkan hasil penelitian di atas, dapat disampaikan saran sebagai berikut; guru sebaiknya membiasakan menerapkan model Picture and Picture dalam pembelajaran menulis deskripsi sebagai upaya untuk meningkatkan hasil belajar siswa berupa keterampilan menulis deskripsi.

\section{Daftar Pustaka}

Arikunto, Suharsimi. (2010). Penelitian Tindakan Kelas. Jakarta: Bumi Aksara.

Arikunto, Suharsimi. (2012). Prosedur Penelitian: Suatu Pendekatan Praktik. Rineka Cipta. Jakarta.

Hamdani. (2011). Strategi Belajar Mengajar. Bandung: Pustaka Setia.

Jayanti, F., \& Fachrurazi, F. (2020). Peningkatan Keterampilan Menulis Karangan Deskripsi Melalui Metode Discovery dengan Menggunakan Media Gambar pada Mahasiswa Program Studi Pendidikan Bahasa dan Sastra Indonesia STKIP Pontianak. Jurnal Kependidikan: Jurnal Hasil Penelitian dan Kajian Kepustakaan di Bidang Pendidikan, Pengajaran dan Pembelajaran, 6(2), 329-339. doi:https://doi.org/10.33394/jk.v6i2.2491 
Lestari, Anik Puji. (2011). Peningkatan Keterampilan Menulis Cerita Pendek dengan Model Pembelajaran Picture And Picture pada Siswa Kelas II SD Negeri 01 Jaten Karanganyar Tahun Pelajaran 2010/2011. Surakarta: Universitas Sebelas Maret. Diunduh dari Digital Library Universitas Sebelas Maret. (Accesed 18/06/2021, pukul: 21:07).

Miftachudin. (2011). Peningkatan Keterampilan Menulis Narasi Melalui Model Picture and Picture pada Siswa Kelas III SDN Turi 2 Kota Blitar. Malang : Universitas Negeri Malang. Diunduh dari Digital Library Universitas Negeri Malang. (Accesed 18/06/2021, pukul: 20:30).

Pereturan Pemerintah No 13 Tahun 2015 Tentang Standar Nasional Pendidikan.

Rusman, dkk. (2011). Model-Model Pembelajaran. Jakarta: Rajagarfindo Persada.

Sadiman, Arief. (2011). Media Pendidikan. Jakarta: Rajawali Pers.

Santosa, dkk. (2008). Materi dan Pembelajaran Bahasa Indonesia SD. Jakarta: Universitas Terbuka.

Syarif, Elina. (2009). Pembelajaran Menulis. Jakarta: Depdiknas.

Sugiyono. (2017). Metode Penelitian Kuantitatif, Kualitatif, dan R\&D. Bandung : Alfabeta.

Suprijono, Agus. (2009). Cooperatif Learning: Teori dan Aplikasi. Yogyakarta: Pustaka Pelajar.

Tarigan, Henry Guntur. 2008). Menulis Sebagai Suatu Keterampilan Berbahasa. Bandung: Percetakan Angkasa.

Wahyuni, L. (2020). Mengembangkan Kemampuan Sosial Anak Usia 4-5 Tahun Melalui Permainan Kartu Bergambar di TK Al Hamidy Mataram. Jurnal Paedagogy, 7(1), 43-51. doi:https://doi.org/10.33394/jp.v7i1.2514 